\title{
ANTIFUNGAL ACTIVITY OF SOME LACTIC ACID BACTERIA AGAINST AFLATOXIN -PRODUCING ASPERGILLI
}

\author{
(Received : 23.11. 2014)
}

\author{
By \\ H. M. Saleh, Y. H. Shetaia ${ }^{*}$, H. A. Fahmy and H. Mahdy ${ }^{\text {** }}$ \\ Special and Nutrition Department, Agricultural Research Center, Dokki, Giza, Egypt. \\ * Department of Microbiology, Faculty of Science. Ain Shams University, Cairo ,Egypt . \\ ** Department of Microbiology, Faculty of Science. El Azhar University, Cairo ,Egypt .
}

\begin{abstract}
This study was performed to investigate the antifungal activity of lactic acid bacterial (LAB) strains. Seven bacterial strains were tested against four fungal isolates that were isolated from infected corn grains and identified as Aspergillus flavus, Aspergillus parasiticus, Aspergillus niger and Rhizopus nigricans. The fungal biomass inhibition method was used as a pre-screening test. The aflatoxin-producing Aspergilli were detected by the black-light method. Aspergillus parasiticus produced both B and $\mathrm{G}$ aflatoxins while Aspergillus flavus produced only B aflatoxins. Twelve LAB strains were screened for antifungal activity against two aflatoxin-producing Aspergilli. The tested LAB strains were Lactobacillus acidophilus ATCC 20552, Lactobacillus acidophilus NRRL-B-4495, Lactobacillus acidophilus LA3, Lactobacillus acidophilus, Lactobacillus plantarum ATCC 14917, Lactobacillus casei DSM 20011, Lactobacillus rhamnosus, Bifidobacterium bifidium, Bifidobacterium longum 15708, Bifidobacterium lactis (Bb12), Streptococcus thermophiles, Streptococcus thermophiles ATCC-3. The antifungal activity was performed by three methods; in the Overlay method, the maximum inhibitions of $A$. flavus and A. parasiticus were obtained by $S$. thermophiles ATCC-3. While, in the well diffusion method, the maximum inhibitions of A. flavus were obtained by B. lactis $(38.0 \mathrm{~mm})$ and $B$. longum $(37.0 \mathrm{~mm})$ and in case of A. parasiticus, the maximum inhibition was obtained by $B$. lactis $(35.0 \mathrm{~mm})$. Whereas, in the agar dilution method; the maximum inhibitions of A. flavus were shown by B. lactis (70.3\%), L. casei DSM $20011(57.77 \%)$ and S. thermophiles ATCC-3 $(57.46 \%)$, respectively and in case of A. parasiticus the maximum inhibitions were obtained by B. bifidum (84.59\%), B. lactis (82.66\%) and S. thermophiles ATCC-3 (68.69\%). This inhibition may be due to the production of antifungal compounds like organic acids, hydrogen peroxide, diacetyl and proteinaceous substances. HPLC analysis indicated that lactic and acetic acids represented the main organic acids in the cell-free extract of lactic acid bacteria.
\end{abstract}

Key words: Inhibition, Lactic acid bacteria, Aflatoxin-producing Aspergilli.

\section{INTRODUCTION}

Certain molds and yeasts represent significant spoilage contaminants of food and feed. In addition, the potential production of toxic and carcinogenic mycotoxins by moulds is of particular concern. Also, fungal spoilage of food causes a significant economic loss. Worldwide, about 5-10\% of the food production is estimated to be spoiled by these organisms (Pitt and Hocking, 2009; Aunsbjerg, 2015).

Lactic acid bacteria are among the most powerful prokaryotes when it comes to antimicrobial potential. These bacteria not only produce several antimicrobials during carbon source metabolism, but also compete with other species by acidifying their environment and by rapidly depleting the nutrients. Besides these relatively simple antagonistic mechanisms, some lactic acid bacteria also produce potent antibiotic compounds via complex secondary metabolism pathways. Oranusi et al., (2013) indicated that the LAB isolates optimized and improved could be used as a natural, food-grade biopreservative agent for management of fungal contamination and food spoilage. Thus preventing problems associated with mycotoxins in food and feed products.

The antifungal compounds of lactic acid bacteria have potential for being effective in combating food borne yeasts and moulds. There 
have been several reports on antifungal properties of lactobacilli; e.g. Lactobacillus acidophilus (Batish et al., 1989, 1990b; Plockova' et al., 1997a, b), L. casei (Suzuki et al., 1991; Gourama, 1997), L. coryniformis subsp. coryniformis (Magnusson and Schnürer, 2001), L. pentosus (Okkers et al., 1999), L. plantarum (Niku-Paavola et al., 1999; Lavermicocca et al., 2000; Laitila et al., 2002; Ström et al., 2002; Lavermicocca et al., 2003), L. rhamnosus (Suzuki et al., 1991; Stiles et al., 2002), L. salivarius (Stiles et al., 1999), L. sanfrancisco (Gobetti and Corsetti, 1997; Corsetti et al., 1998), L. lactis subsp. lactis (Roy et al., 1996; Roy et al., 2001) and L. lactis subsp. lactis var. diacetylactis (Batish et al., 1989, 1990a).

Furthermore, it has been shown that certain LAB, such as a dairy strain Lactococcus lactis, as well as Lactobacillus and Pediococcus meat starters, silage mixtures containing $L$. acidophilus, $L$. bulgaricus and $L$. plantarum species and probiotic L. rhamnosus strains either suppress mycotoxin biosynthesis or effectively remove preformed mycotoxins (Coallier-Ascah and Idziak , 1985; Luchese et al. 1992; Gourama and Bullerman 1995b, 1997; El-Nezami and Ahokas 1998; El-Nezami et al., 1998a, 1998b; Haskard et al. 2001).

El-Gendy and Marth (1981) reported that Lactobacillus casei inhibited the growth and the aflatoxin production of Aspergillus parasiticus. Also, Lavermicocca et al. (2000) demonstrated that the antifungal compounds such as phenyl lactic acid and 4-hydrophenyllactic acid were produced by Lactobacillus plantarum.

Most of the antifungal capacity of the lactic acid bacteria e.g. Lactobacillus acidophilus
NCIM5426 and Lactobacillus amylovorus DCE 471 is due to the production of an antifungal protein or proteinaceous compound. Others like $L$. plantarum and $L$. sanfrancisco produce special organic acids (3-phenyl-L-lactic acid and caproic acid, respectively) that have antifungal properties (Corsetti et al., 1998; Ström et al., 2002; Lavermicocca et al., 2003).

The aim of the present research was to screen and evaluate the antifungal activity of lactic acid bacterial strains against aflatoxin-producing Aspergilli. As the inhibition of toxigenic fungi by LAB could be of great public health significance.

\section{MATERIALS AND METHOD}

\subsection{Lactic acid bacterial cultures}

Lactobacillus acidophilus ATCC 20552, Lactobacillus acidophilus and Streptococcus thermophilus were originally obtained from Chr. Hansen's Lab (Denmark). Lactobacillus rhamnosus, Bifidobacterium bifidum and Bifidobacterium longum 15708 were collected from a dairy research lab in the Agriculture Research Center (ARC). Lactobacillus acidophilus NRRL-B-4495, Lactobacillus acidophilus, Lactobacillus plantarum ATCC 14917, Streptococcus thermophilus ATCC-3 and Bifidobacterium lactis (Bb12) were obtained from the laboratory of microbiology in the Agricultural Research Center. Lactobacillus casei DSM 20011 was obtained from MERCIN, while Lactobacillus acidophilus LA3 was obtained from the Dept. of Food Nutrition Sciences, College of Agriculture, King Faisal University. All the Lactobacillus strains were cultured according to their specific requirements of temperature and aeration level as shown in

Table (1): Culture conditions and specific requirements of temperature and aeration level of lactic acid bacteria.

\begin{tabular}{|c|c|c|c|c|}
\hline Species & Medium & Temperature & Condition & Incubation time \\
\hline Lactobacillus acidophilus ATCC 20552 & MRS & $37^{\circ} \mathrm{C}$ & Anaerobic & $24-48 \mathrm{~h}$ \\
\hline Lactobacillus acidophilus NRRL-B-4495 & MRS & $37^{\circ} \mathrm{C}$ & Anaerobic & 24-48 h \\
\hline Lactobacillus acidophilus LA3 & MRS & $37^{\circ} \mathrm{C}$ & Anaerobic & $24-48 \mathrm{~h}$ \\
\hline Lactobacillus acidophilus & MRS & $37^{\circ} \mathrm{C}$ & Anaerobic & $24-48 \mathrm{~h}$ \\
\hline Lactobacillus casei DSM 20011 & MRS & $30^{\circ} \mathrm{C}$ & Aerobic & $24-48 \mathrm{~h}$ \\
\hline Lactobacillus plantarum ATCC 14917 & MRS & $30^{\circ} \mathrm{C}$ & Aerobic & $24-48 \mathrm{~h}$ \\
\hline Lactobacillus rhamnosus & MRS & $37^{\circ} \mathrm{C}$ & Aerobic & $24-48 \mathrm{~h}$ \\
\hline Bifidobacterium lactis (Bb12) & MRS-cys & $37^{\circ} \mathrm{C}$ & Anaerobic & $48-72 \mathrm{~h}$ \\
\hline Bifidobacterium longum 15708 & MRS-cys & $37^{\circ} \mathrm{C}$ & Anaerobic & $48-72 \mathrm{~h}$ \\
\hline Bifidobacterium bifidum & MRS-cys & $37^{\circ} \mathrm{C}$ & Anaerobic & $48-72 \mathrm{~h}$ \\
\hline Streptococcus thermophilus ATCC-3 & Eliker & $42^{\circ} \mathrm{C}$ & Anaerobic & $24-48 \mathrm{~h}$ \\
\hline Streptococcus thermophilus & Eliker & $42^{\circ} \mathrm{C}$ & Anaerobic & $24-48 \mathrm{~h}$ \\
\hline
\end{tabular}


(Table 1). Anaerobic strains were kept in an anaerobic jar (Gas Generating Kit, Oxoid England ). Again, fully grown colonies were stored on plates at $4{ }^{\circ} \mathrm{C}$ until further use.

\subsection{The fungal isolates and culture condition}

In this study the fungal isolates were isolated from infected corn grains on Potato Dextrose Agar (PDA), and their identification was based on macroscopically and microscopically features (Domsch et al., 1980; Von Arx ,1981; Hanlin, 1990; Kiffer and Morelet,1997). All isolates were cultured on (Difco Laboratories, Detroit, Mich USA.) plates at $25^{\circ} \mathrm{C}$. Once good growth of the cultures was established, they were stored at $4^{\circ} \mathrm{C}$ until further use.

\subsection{Preparation of spore suspension}

The fungal cultures were grown on PDA slants for 7 to 10 days at $25^{\circ} \mathrm{C}$ until well sporulated. The fungal spores were harvested by adding $10 \mathrm{ml}$ of sterile water and aseptically dislodging the spores with a sterile inoculating loop. The spore suspensions were further adjusted with sterile water to give a final spore concentration of approximately $10^{4}$ spores / ml by a haemocytometer. The spore concentration was determined on PDA plates using standard pour plate technique at $25{ }^{\circ} \mathrm{C}$ for 2 to 3 days. The PDA used in this study was not acidified, and the $\mathrm{pH}$ of this medium after sterilization was $5.6 \pm 0.2$ (Siriporn et al., 2003).

\subsection{Preparation of culture supernatants of lactic acid bacteria}

Cell-free culture supernatants (CFCS) of lactic acid bacteria were obtained by centrifugation $\left(10,000 \times \mathrm{g}, 4{ }^{\circ} \mathrm{C}, 10 \mathrm{~min}\right)$ of lactobacilli cells grown in $20 \mathrm{ml}$ MRS broth (Difco Laboratories, Detroit, MichUSA.) at 37 ${ }^{\circ} \mathrm{C}$ for $24 \mathrm{~h}$. The supernatant was filtered through a $0.22 \mu \mathrm{m}$ filter to remove residual cells (Ogunbanwo, 2005).

\subsection{Pre-screening test of the antifungal activity}

\subsubsection{Fungal biomass inhibition method}

A pre-screening test was performed by using seven strains of lactic acid bacteria against four fungal isolates. This method was based on dry weight measurements of fungal biomass. The percentage of inhibition of fungal growth was calculated by comparing the fungal growth of the control with the treated one. After five days of incubation, the dry weight of the mycelia was obtained on apre-weight filter paper in an oven at $60{ }^{\circ} \mathrm{C}$ for $48^{\circ} \mathrm{h}$. The means were calculated and the percentage of inhibition was calculated using the formula:

$$
\frac{R 1-R 2}{R 1} * 100
$$

Where, R1 is the dry weight of the control and R2 the dry weight of the treated fungus (Siriporn et al., 2003).

\subsection{Detection of aflatoxin- producing} Aspergilli

The aflatoxin- producing Aspergilli can be detected by the black-light method which correctly identifies negative AFs samples. It depends on the illumination of the sample with a UV lamp. The test should be made in a darkened area for best contrast. Fluorescence may be bright or dim, depending on the amount of fluorescing agent present (Irineo Torres, 2011).

\subsection{Assessment of the MIC of aflatoxin- producing Aspergilli}

The antifungal activity of twelve strains of lactic acid bacteria was screened against the two aflatoxin-producing Aspergilli. In these tests one milliliter of the final spore suspension containing about $10^{4}$ spores / $\mathrm{ml}$ of $A$. flavus and $A$. parasiticus was inoculated individually in 250 ml Erlenmeyer flasks containing $20 \mathrm{ml}$ MRS. Different concentrations of the selected LAB supernatants $(10,15,20,25,50$ and $75 \%)$ were added to the flasks. The cultures were then incubated for 5 days at $25{ }^{\circ} \mathrm{C}$. In the control experiment, only spore suspension was added to sterile MRS broth. After 5 days of incubation, the fungal mycelium was dried on a pre-weight filter paper in oven at $60^{\circ} \mathrm{C}$ for $48^{\circ} \mathrm{h}$ and weighted. The means were calculated from the previous formula.

\subsection{Methods for evaluation of antifungal activity}

Among many methods available for evaluation of antifungal activity (Parish and Davidson 1993), three methods described below have been used for determining the antifungal activity of the compounds produced by LAB.

\subsubsection{Antifungal overlay assay}

The antifungal activity of LAB was investigated with an overlay assay (Lind et al., 2005; Magnusson and Schnürer, 2001). Among the different fungal species studied, A. flavus and A. parasiticus were finally selected in the initial screening then further evaluated. LAB bacteria were inoculated in two lines $(2-\mathrm{cm})$ on MRS agar plates and allowed to grow at $30{ }^{\circ} \mathrm{C}$. Ten milliliters of soft (7\%) PDA agar containing 1 $\mathrm{ml}$ of fungal inoculum were poured and incubated at $30^{\circ} \mathrm{C}$. After $48 \mathrm{~h}$, the zone of inhibition was measured. The degree of inhibition was calculated as the area of inhibited 
growth in relation to the total area of the Petri dish and the scale was represented as follow: (-) $=$ no visible inhibition, $(+)=$ weak inhibition in the soft agar, $(++)=$ medium inhibition, $(+++)=$ strong inhibition, $(++++)=$ very strong inhibition and $(-)=$ no visible inhibition.

\subsubsection{The agar diffusion method}

The agar diffusion method has long been used for testing antimicrobial activity. It includes agar well diffusion assay and disc assay. In this test, an antimicrobial compound is applied to an agar plate on a paper disc or in a well. The results of the test are generally qualitative (Parish and Davidson, 1993).

\subsubsection{The well-diffusion assay}

The antifungal activity of cell free supernatants of the selected LAB was used against the aflatoxin-producing Aspergilli by the agar well diffusion technique. In this test, an antimicrobial compound is applied to a well in an agar plate containing $20 \mathrm{ml}$ PDA media. The plates were inoculated with the fungal isolate and incubated at $25{ }^{\circ} \mathrm{C}$ for $24-48 \mathrm{~h}$ and the antimicrobial effect was recorded by measuring the zone of inhibition around the well. The experiment was carried out in duplicates (Parish and Davidson 1993).

\subsubsection{The disc diffusion assay}

The antifungal activity of cell free supernatants of the selected LAB was tested with the filter disk method. In this test, the CFS (100 $\mu \mathrm{l})$ were applied to a paper disc on an agar plate containing $20 \mathrm{ml}$ of the inoculated PDA media. The plates were incubated at $25{ }^{\circ} \mathrm{C}$ for $24-48 \mathrm{~h}$ and the antimicrobial effect was recorded by measuring the zone of inhibition around the disc. The experiment was carried out in duplicates (Parish and Davidson 1993).

\subsubsection{The agar dilution method}

The antifungal activity was carried out by agar dilution method (Mitscher et al., 1972). The antifungal activity was evaluated against these fungal isolates (A. flaves and A. parasiticus) using a concentration of $500 \mu \mathrm{l}$ of the LAB extract incorporated into the media and poured into the different petriplates and allowed to solidify. Fungal plugs $(0.6 \mathrm{~mm}$ in diameter) were obtained and placed at the center of Petri dishes containing a Potato Dextrose Agar (PDA) culture media with the LAB extract. The PDA plates containing only fungal plugs were used as control plates. All plates were incubated at $28{ }^{\circ} \mathrm{C}$ and the radial growth of mycelia was measured daily during 7 days. The control one; presented a fast radial growth of mycelium and reached the edge of the plates. The percentage of inhibition was calculated on the basis of growth in the control plates as:

Percentage of mycelial growth inhibition

$$
=\frac{\begin{array}{l}
\text { Mycelial growth }- \text { Mycelial growth } \\
\text { in control }
\end{array} \text { in the treated one }}{\text { Mycelial growth in control }} * 100
$$

\subsection{Determination of antifungal metabolites} produced by LAB strains

2.9.1. Analysis of the organic acids by the High Performance Liquid Chromatography (HPLC)

\subsubsection{Sample preparation}

The LAB cultures were grown in $10 \mathrm{ml}$ MRS broth at $37^{\circ} \mathrm{C}$, then the cultures were centrifuged at $10000 \mathrm{rpm}$, for $15 \mathrm{~min}$. The organic acids were determined in the CFS after $16 \mathrm{~h}, 48 \mathrm{~h}, 20 \mathrm{~h}, 24 \mathrm{~h}$ and $48 \mathrm{~h}$ of the bacterial growth. Then $1 \mathrm{ml}$ supernatant from each strain was filtered through $0.22 \mu \mathrm{m}$ membrane filter without dilution to be measured by a HPLC.

\subsubsection{Analysis by HPLC}

Organic acid concentration in the CFCS was measured by a HPLC (Agilent Technologies 1200 series, Calif. US) and the system was equipped with auto sampler, column compartment set at $35^{\circ} \mathrm{C}$, quaternary pump set at flow rate $1 \mathrm{ml} / \mathrm{min}$, and injection volume of sample $(15 \mu 1)$.The organic acid was detected with MWD (Multi Wavelength Detector) at 210 $\mathrm{nm}$. The sample was fractionated by using Ao1000 column Alltech $(300 \times 6.5 \mathrm{~mm})$ and Acid identification was performed by comparing the retention times of the samples with that of the standards of organic acid (Sigma Aldrich Co. LLC. US/Canada).

\section{RESULT AND DISCUSSION}

\subsection{Pre-screening the antifungal activity}

Based on dry weight measurements of fungal biomass, all tested lactic acid bacterial strains inhibited the growth of four fungal isolates Aspergillus flavus, Aspergillus parasiticus, Aspergillus niger and Rhizopus nigricans to varying extents except lactobacillus plantarum strain as shown in (Table 2). The fungal growth on liquid MRS medium inoculated with lactic acid bacteria was expressed as the percentage of the decrease of fungal biomass in comparison to the control.

A high percentage of lactic acid bacteria (LAB) was observed to possess antifungal activity inhabiting all the four spoilage fungi within the incubation period. The percentage inhibition of the fungal growth of $A$. parasiticus 
Table (2): Percentage inhibition of fungal growth by using cell-free bacterial supernatants of LAB strains.

\begin{tabular}{|c|c|c|c|c|c|c|c|c|}
\hline \multirow{3}{*}{ Strains of Lactic acid bacteria } & \multicolumn{8}{|c|}{$\%$ inhibition of fungal growth } \\
\hline & \multicolumn{2}{|c|}{ A. parasiticus } & \multicolumn{2}{|c|}{ A. flavus } & \multicolumn{2}{|c|}{ A. niger } & \multicolumn{2}{|c|}{ R. nigricans } \\
\hline & 0.3154 & $\%$ & 0.3063 & $\%$ & 0.352 & $\%$ & 0.3154 & $\%$ \\
\hline Lactobacillus acidophilus ATCC 20552 & 0.0548 & 82.6 & 0.102 & 66.7 & 0.113 & 67.9 & 0.1127 & 64.3 \\
\hline Lactobacillus acidophilus NRRL-B-4495 & 0.0866 & 72.54 & 0.0851 & 72.2 & 0.088 & 75.0 & 0.1861 & 41.0 \\
\hline Lactobacillus bulgaricus & 0.0565 & 82.09 & $\mathbf{0 . 0 5 0 7}$ & 83.5 & 0.055 & 84.4 & 0.056 & 82.2 \\
\hline Bifidobacterium lactis (Bb12) & 0.0392 & 87.75 & 0.0471 & 84.6 & $\mathbf{0 . 0 5 3}$ & 85.0 & $\mathbf{0 . 0 3 8 3}$ & 87.9 \\
\hline Lactobacillus plantarum & 0.3494 & 10.78- & 0.3555 & 13.8- & 0.395 & 12.2- & 0.2009 & 36.3 \\
\hline Lactobacillus plantarum ATCC 14917 & 0.0400 & 87.32 & 0.0805 & 73.7 & 0.084 & 76.2 & $\mathbf{0 . 0 3 6 5}$ & 88.4 \\
\hline Streptococcus thermophiles ATCC-3 & 0.0564 & 82.12 & 0.0403 & 86.8 & 0.049 & 86.0 & 0.0451 & 85.7 \\
\hline
\end{tabular}

ranged from 72.54 in Lactobacillus acidophilus NRRL-B-4495 to 87.75 in Bifidobacterium lactis (Bb12), respectively in comparing with the controls grown in MRS. Also, the percentage inhibition of the fungal growth of A. flavus and A. niger ranged from 66.7 and 67.9 in Lactobacillus acidophilus ATCC 20552 to 86.8 and 86.0 in Streptococcus thermophiles ATCC3 , respectively. While, the percentage inhibition of fungal growth of $R$. nigricans ranged from 41.0 in Lactobacillus acidophilus NRRL-B-4495 to 88.4 in Lactobacillus plantarum ATCC 14917.

The three fungal isolates (A. flavus, A. parasiticus and $A$. niger) showed no growth inhibition by cell free culture supernatant from Lactobacillus plantarum, while the other strain of L. plantarum ATCC 14917 inhibited the fungal growth by $87.3 \%$ in case of $A$. parasiticus, $73.7 \%$ in A. flavus, $76.2 \%$ in A. niger and $88.4 \%$ in $R$. nigricans.

L. plantarum ATCC 14917 achieved the highest inhibition percentage (88.4\% ) against $R$. nigricans, also, Bifidobacterium lactis (Bb12) achieved the highest inhibition percentage $(87.75 \%)$ against A. parasiticus. while, Streptococcus thermophiles ATCC-3 achieved the highest inhibition percentages $(86.8 \%)$ and (86 \%) against $A$. flavus and $R$. niger, respectively.

The results of the dry weight of mycelia indicated the suppressive effect of LAB on the fungal growth due to the production of several metabolites that may act together to inhibit fungal growth in liquid culture.

The antifungal activity of lactobacilli may be due to their ability to produce fungistatic bacteriocin-like substance, phenyllactic acid and 4-hydroxyphenyllactic acid, short-chain fatty acids and low-molecular-weight substances, such as benzoic acid, methylhydantoin, mevalonolactone and cyclo (Gly-L-Leu)
(Corsetti et al., 1998; Okkers et al., 1999; NikuPaavola et al., 1999 and Lavermicocca et al., 2003). Gourama and Bullerman (1995 and 1997) showed that a commercially available silage inoculant with a combination of Lactobacillus species had antifungal and antiaflatoxin activity against A. flavus. Also, Lavermicocca et al., (2000) reported that phenyllactic acid and 4hydroxy-phenyllactic acid from $L$. plantarum $21 \mathrm{~B}$, were used with their antifungal activity against several species of filamentous fungi. Phenyllactic acid has also been identified from culture supernatants of $L$. plantarum MiLAB 393 (Ström et al., 2002). Antifungal metabolites, e.g. peptides, phenyllactic acid, proteinaceous compounds and 3-hydroxylated fatty acids have also been isolated from lactic acid bacteria (Schnürer and Magnusson, 2005).

\subsection{Detection of aflatoxin- producing fungi}

When the fungal isolates were exposed to the UV lamp, it was found that two strains were positive AFs (as they produce blue fluorescence which associated with the aflatoxin production). They include Aspergillus parasiticus, produced both $B$ and $G$ aflatoxins while the other identified as Aspergillus flavus, produced only B aflatoxins.

\subsection{Assessment of the MIC of aflatoxin- producing Aspergilli}

In this test six different concentrations of the cell-free supernatants of the selected five LAB strains were examined against both aflatoxinproducing Aspergilli (A. flavus and A. parasiticus). The obtained results are summarized in Tables ( $3 \& 4)$. The increasing of the supernatant concentration from $10 \%$ to $25 \%$ accompanied a decrease in the dry weights of the tested fungi. But in the case of using supernatant concentrations from $50 \%$ to $75 \%$, there was no detectable growth for both of the tested fungal isolates.

The highest antifungal activity was obtained 
by $B$. lactis (Bb12) which has the MIC at supernatant concentration $<10 \%$ against both, $A$. flavus and A. parasiticus, respectively. A moderate antifungal activity was detected by both $L$. acidophilus NRRL-B-4495 and $L$. plantarum ATCC 14917, which have the MIC at supernatant concentration at $20 \%$ against $A$. flavus and only L. acidophilus NRRL-B-4495 has the MIC at supernatant concentration at $20 \%$ against $A$. parasiticus. The lowest antifungal activity was observed by $L$. acidophilus ATCC 20552 and $S$. thermophiles as they have the MIC at supernatant concentration of $50 \%$ against $A$. flavus; also, L. acidophilus ATCC 20552 and $L$. plantarum ATCC 14917 have MIC at supernatant concentration of $50 \%$ against $A$. parasiticus. The reduction of fungal sporulation may be referred to the inhibitory activity of lactic acid bacterial strains (Onilude et al., 2005).

In this study, B. lactis (Bb12), L. acidophilus ATCC 20552 and L. plantarum ATCC 14917 had a higher antifungal activity against $A$. flavus and $A$. parasiticus than the other tested lactic acid bacteria. A. flavus was more sensitive than A. parasiticus to the cell-free supernatant and its dilution. The antifungal activity of lactobacilli may be due to their ability to produce fungistatic bacteriocin-like substance, phenyllactic acid and 4-hydroxyphenyllactic acid, short-chain fatty acids and low-molecular weight substances, such as benzoic acid, methylhydantoin, mevalonolactone and cyclo (Gly-L-Leu) as reported by (Corsetti et al., 1998; Niku et al., 1999; Okkers et al., 1999; Lavermicocca et al., 2003; Dalié et al., 2010). The inhibition effect of L. plantarum ATCC 14917 was similar to the inhibition effect that shown by L. plantarum YO which was able to inhibit the vegetative and sporulative growth of all aflatoxin producing Aspergilli (Ghonaimy et al., 2007).

\subsection{Methods for evaluation of antifungal activity}

The present study was undertaken to demonstrate the mycelial growth inhibition of the two aflatoxin-producing Aspergilli (A. flavus and $A$.parasiticus) by the presence of both the lactic acid bacterial (LAB) cells and their cellfree culture supernatants (CFNS) using different bioassays. Several methods for detecting activity are available, but since they are not equally sensitive or not based upon the same principle, results will be profoundly influenced by the method. The methodology for testing natural compounds for the determination of antifungal activity is variable and each research group includes different types of tests.

\subsubsection{The overlay method}

The antifungal activity of twelve LAB strains was evaluated by the overlay method. As shown from the results in (Table 5), there are varying inhibition levels of the growth of each of A. flavus and $A$. parasiticus to the antifungal agents produced by lactic acid bacterial strains.

As all LAB strains tested showed antifungal activity. Streptococcus thermophiles ATCC-3 was very highly active (++++) against $A$. flavus and has moderate activity (++) against $A$. parasiticus. Bifidobacterium lactis (Bb12) and Lactobacillus casei DSM 20011 were highly active (+++) against $A$. flavus and have moderate activity (++) against A. parasiticus.

The inhibitory activity of the tested bacteria could be seen because all metabolites; lactic acid, acetic acid, diacetyl, bacteriocin etc., are present and being produced during the assay period and this agreed with (Çon and Gökalp, 2000). Other studies suggested that antifungal activity of LAB is due to a synergistic effect of lactic acid produced by the bacteria and acetic acid from the MRS growth medium (Cabo et al., 2002). It might has been due to the fact that the antimicrobial compounds in the mixtures interacted with each other as well as with the tested organisms (Niku-Paavola et al., 1999).

\subsubsection{The agar diffusion method \\ 3.4.2.1. The well-diffusion assay}

The cell-free supernatants (CFS) of the selected LAB strains produced antifungal activities against the two aflatoxin-producing Aspergilli as in (Table 6).

The largest zone of inhibition $(38.0 \mathrm{~mm})$ was produced by Bifidobacterium lactis (Bb12) against $A$. flavus and $(35.50 \mathrm{~mm})$ against $A$. parasiticus (Table, 6). While, Bifidobacterium longum 15708 produced a moderate inhibition zone $(37 \mathrm{~mm})$ against A. flavus and $(33.0 \mathrm{~mm})$ against $A$. parasiticus. On the other hand, lactobacillus and streptococcus strains achieved high inhibition zones but less than obtained by Bifidobacterium strains.

\subsubsection{The disc diffusion assay}

The assessment of antifungal activity of 12 lactic acid bacterial strains using disc diffusion method is presented in (Table 7).

As shown from the results of (Table, 7), the highest inhibition zone was observed with Bifidobacterium longum 15708 against A. flavus $(11.0 \mathrm{~mm})$ and A.parasiticus $(7.5 \mathrm{~mm})$. While, 
Table (3): Assessment of MIC of lactic acid bacterial supernatants against Aspergillus flavus.

\begin{tabular}{|l|c|c|c|c|c|c|c|}
\hline \multirow{2}{*}{ Lactic acid bacteria } & \multicolumn{7}{|c|}{ Supernatant concentration (\%) } \\
\cline { 2 - 8 } & $\mathbf{0 \%}$ (control) & $10 \%$ & $15 \%$ & $\mathbf{2 0 \%}$ & $\mathbf{2 5 \%}$ & $\mathbf{5 0 \%}$ & $\mathbf{7 5 \%}$ \\
\hline L. acidophilus ATCC 20552 & $\mathbf{0 . 3 1}$ & $\mathbf{0 . 2 8 2}$ & $\mathbf{0 . 2 7 2}$ & $\mathbf{0 . 2 4 2}$ & $\mathbf{0 . 2 1 1}$ & ND & ND \\
\hline L. acidophilus NRRL 4495 & $\mathbf{0 . 3 1}$ & $\mathbf{0 . 2 3 3}$ & $\mathbf{0 . 1 9 3}$ & ND & ND & ND & ND \\
\hline L. plantarum ATCC 14917 & $\mathbf{0 . 3 1}$ & $\mathbf{0 . 2 5 6}$ & $\mathbf{0 . 2 1 2}$ & ND & ND & ND & ND \\
\hline B. lactis( Bb12) & 0.31 & ND & ND & ND & ND & ND & ND \\
\hline S. thermophiles ATCC-3 & $\mathbf{0 . 3 1}$ & $\mathbf{0 . 2 4 2}$ & $\mathbf{0 . 2 1 0}$ & $\mathbf{0 . 2 0 6}$ & $\mathbf{0 . 1 7 4}$ & ND & ND \\
\hline
\end{tabular}

Table (4): Assessment of MIC of lactic acid bacterial supernatants against Aspergillus parasiticus.

\begin{tabular}{|l|c|c|c|c|c|c|c|}
\hline \multirow{2}{*}{ Lactic acid bacteria } & \multicolumn{7}{|c|}{ Supernatant concentration (\%) } \\
\cline { 2 - 8 } & $\mathbf{0 \%}$ (control) & $10 \%$ & $15 \%$ & $20 \%$ & $\mathbf{2 5 \%}$ & $\mathbf{5 0 \%}$ & $\mathbf{7 5 \%}$ \\
\hline L. acidophilus ATCC 20552 & $\mathbf{0 . 3 2}$ & $\mathbf{0 . 2 8 2}$ & $\mathbf{0 . 2 5 2}$ & $\mathbf{0 . 2 3 2}$ & $\mathbf{0 . 2 1 8}$ & ND & ND \\
\hline L. acidophilus NRRL 4495 & $\mathbf{0 . 3 2}$ & $\mathbf{0 . 2 3 3}$ & $\mathbf{0 . 1 6 0}$ & ND & ND & ND & ND \\
\hline L. plantarum ATCC 14917 & $\mathbf{0 . 3 2}$ & $\mathbf{0 . 2 6 7}$ & $\mathbf{0 . 2 4 6}$ & $\mathbf{0 . 2 4 0}$ & $\mathbf{0 . 2 1 4}$ & ND & ND \\
\hline B. lactis( Bb12) & $\mathbf{0 . 3 2}$ & ND & ND & ND & ND & ND & ND \\
\hline S. thermophiles ATCC-3 & $\mathbf{0 . 3 2}$ & $\mathbf{0 . 2 4 6}$ & $\mathbf{0 . 2 3 6}$ & $\mathbf{0 . 2 3 1}$ & ND & ND & ND \\
\hline
\end{tabular}

Table (5): The antifungal activity of some lactic acid bacterial strains against the fungal isolates (A. flavus, $A$. parasiticus) using the overlay assay.

\begin{tabular}{|l|c|c|}
\hline \multicolumn{1}{|c|}{ Lactic acid bacteria } & \multicolumn{2}{c|}{ Fungal isolates } \\
\cline { 2 - 3 } & Aspergillus flavus & Aspergillus parasiticus \\
\hline Lactobacillus acidophilus NRRL-B-4495 & + & + \\
\hline Lactobacillus acidophilus ATCC 20552 & + & + \\
\hline Lactobacillus acidophilus LA3 & + & ++ \\
\hline Lactobacillus acidophilus & + & ++ \\
\hline Streptococcus thermophiles ATCC-3 & ++++ & ++ \\
\hline Streptococcus thermophiles & ++ & + \\
\hline Lactobacillus plantarum ATCC 14917 & + & ++ \\
\hline Lactobacillus rhamnosus & + & ++ \\
\hline Bifidobacterium lactis (Bb12) & +++ & + \\
\hline Bifidobacterium longum 15708 & + & + \\
\hline Bifidobacterium bifidium & ++ & ++ \\
\hline Lactobacillus casei DSM 20011 & +++ & + \\
\hline
\end{tabular}

$(+)=$ weak inhibition, $(++)=$ medium inhibition, $(+++)=$ strong inhibition, $(++++)=$ very strong inhibition and $(-)=$ no visible inhibition

Table (6): Assessment of antifungal activity of lactic acid bacterial strains against $A$. flavus and $A$. parasiticus using the well diffusion method.

\begin{tabular}{|l|c|c|}
\hline \multirow{2}{*}{ Strains of lactic acid bacteria } & \multicolumn{2}{c|}{ Inhibition zone of fungal strains by (mm) } \\
\cline { 2 - 3 } & Aspergillus flavus & Aspergillus parasiticus \\
\hline Lactobacillus acidophilus NRRL-B-4495 & 31.0 & 32.0 \\
\hline Lactobacillus acidophilus ATCC 20552 & 32.0 & 34.0 \\
\hline Lactobacillus acidophilus LA3 & 35.0 & 31.0 \\
\hline Lactobacillus acidophilus & 34.0 & 30.0 \\
\hline Streptococcus thermophilus ATCC-3 & 30.0 & 32.0 \\
\hline Streptococcus thermophilus & 34.0 & 27.0 \\
\hline Lactobacillus plantarum ATCC 14917 & 31.0 & 31.0 \\
\hline Lactobacillus rhamnosus & 32.0 & 22.0 \\
\hline Bifidobacterium lactis (Bb12) & 38.0 & 35.0 \\
\hline Bifidobacterium longum 15708 & 37.0 & 33.0 \\
\hline Bifidobacterium bifidum & 32.0 & 32.0 \\
\hline Lactobacillus casei DSM 20011 & 33.0 & 20.0 \\
\hline
\end{tabular}


Table (7): Assessment of the antifungal activity of some lactic acid bacterial strains against A. flavus and $A$. parasiticus using the disc diffusion method.

\begin{tabular}{|l|c|c|}
\hline \multirow{2}{*}{\multicolumn{1}{|c|}{ Strain of lactic acid bacteria }} & \multicolumn{2}{|c|}{ Inhibition zone of fungal strains by (mm) } \\
\cline { 2 - 3 } & Aspergillus flavus & Aspergillus parasiticus \\
\hline Lactobacillus acidophilus NRRL-B-4495 & 9.0 & 7.0 \\
\hline Lactobacillus acidophilus ATCC 20552 & 7.0 & 6.5 \\
\hline Lactobacillus acidophilus LA3 & 6.5 & 7.0 \\
\hline Lactobacillus acidophilus & 7.5 & 7.0 \\
\hline Streptococcus thermophiles ATCC-3 & 7.0 & 6.5 \\
\hline Streptococcus thermophiles & 7.5 & 6.5 \\
\hline Lactobacillus plantarum ATCC 14917 & 7.8 & 6.5 \\
\hline Lactobacillus rhamnosus & 7.5 & 7.0 \\
\hline Bifidobacterium lactis(Bb12) & 8.0 & 7.5 \\
\hline Bifidobacterium longum ATCC 15708 & 11.0 & 7.5 \\
\hline Bifidobacterium bifidum & 8.0 & 7.0 \\
\hline Lactobacillus casei DSM 20011 & 7.6 & 6.5 \\
\hline
\end{tabular}

the least inhibition zone observed was with Lactobacillus acidophilus LA3 against $A$. flavus (6.5mm). In the case of A. parasiticus, Lactobacillus acidophilus ATCC 20552, Streptococcus thermophiles ATCC-3, S. thermophiles, Lactobacillus plantarum ATCC 14917 and Lactobacillus casei DSM 20011 showed the lowest inhibition zones $(6.5 \mathrm{~mm})$.

In the diffusion method all LAB inhibited the two aflatoxin-producing Aspergilli to varying degrees. It was observed that B. lactis (Bb12) exhibited the highest inhibition values in the well-diffusion assay $(38.0 \mathrm{~mm})$ against $A$. flavus and $(35.0 \mathrm{~mm})$ against $A$. parasiticus. While, $B$ longum ATCC 15708 exhibited the highest inhibition values in the disc-diffusion assay $(11.0 \mathrm{~mm})$ against $A$. flavus and $(7.5 \mathrm{~mm})$ against $A$. parasiticus, respectively. This may be due to the combined effect of lactic acid and bacteriocin.

Vanne et al. (2000) showed that the growth of toxigenic storage fungi was restricted by $\mathrm{LAB}$ in vitro and attributed this to the combined effect of lactic acid and bacteriocin. Motawee et al., (2011) reported that lactic acid bacteria (LAB) and Bifidobaceria, due in large part to their Generally Recognized As Safe (GRAS) status and their use as probiotics, are of particular interest for reducing the bioavailability of aflatoxin produced by Aspergilli.

Bolognani et al., (1997) reported the great efficiency of $B b$. longum to bind carcinogens produced by aflatoxigenic fungi. A number of studies screened these microorganisms for the ability to bind to aflatoxin and have reported a wide range of genus, species and strain specific binding capacities (Haskard et al., 2001; Lee et.al., 2003; Hwang et al., 2005; Zinedine et.al., 2005; Hermandez et al., 2009). A previous study showed that the antagonistic activity exhibited by the LAB strains was completely destroyed by treatment with proteolytic enzymes (Adebayo and Aderiye, 2008). As the antifungal effect therefore could be attributed to the production of bacteriocins by the LAB strains.

On the other hands, some strains of LAB have been shown to inhibit both growth of mold and the production of mycotoxins (El- Shafei et al., 2010). The antagonistic action was produced by catalase-treated, neutralized, cell-free culture filtrates (CFNS), indicating that the antifungal activity was not due to the action of organic acids or hydrogen-peroxide produced by these LAB strains.

\subsubsection{The agar dilution method}

As shown from the results of (Table 8), it was observed that the highest inhibition percentage (70.3\%) was obtained by Bifidobacterium lactis (Bb12) against A. flavus. Bifidobacterium bifidium showed the highest inhibition (84.59\%) against $A$. parasiticus. While the lowest inhibition percentages $(21.82 \%)$ and $(11.87 \%)$ were obtained by Lactobacillus acidophilus LA3 against each of $A$. flavus and A. parasiticus, respectively.

The results showed that all Lactobacillus strains have antifungal activities in varying degrees against fungal isolates. The reduction in radial mycelial growth of fungi in culture PDA media with the cell-free supernatant of 
Table (8): Assessment of the percentage of mycelial growth inhibition by agar dilution assay.

\begin{tabular}{|l|c|c|}
\hline \multirow{2}{*}{ Strains of Lactic acid bacteria } & \multicolumn{2}{c|}{ Fungal isolates (\%) } \\
\cline { 2 - 3 } & Aspergillus flavus & Aspergillus parasiticus \\
\hline Lactobacillus acidophilus NRRL-B-4495 & 29.05 & 21.82 \\
\hline Lactobacillus acidophilus ATCC 20552 & 45.42 & 37.88 \\
\hline Lactobacillus acidophilus LA3 & 21.82 & 11.87 \\
\hline Lactobacillus acidophilus & 41.25 & 71.74 \\
\hline Streptococcus thermophiles ATCC-3 & 57.46 & 68.69 \\
\hline Streptococcus thermophiles & 36.59 & 63.08 \\
\hline Lactobacillus plantarum ATCC 14917 & 47.83 & 54.57 \\
\hline Lactobacillus rhamnosus & 38.84 & 43.82 \\
\hline Bifidobacterium lactis(Bb12) & 70.30 & 82.66 \\
\hline Bifidobacterium longum 15708 & 44.62 & 43.33 \\
\hline Bifidobacterium bifidium & 34.51 & 84.59 \\
\hline Lactobacillus casei DSM 20011 & 57.77 & 43.00 \\
\hline
\end{tabular}

Bifidobacterium strain (Bifidobacterium lactis) was higher than those with lactobacillus strains (L. acidophilus LA3 and L. acidophilus NRRLB-4495). This may be due to the production of proteinaceous compounds such as bacteriocins or bacteriocin-like compounds beside organic acids, hydrogen peroxide, ethanol, diacetyl, acetaldehyde, carbon dioxide and reuterin against undesirable harmful microorganisms. They are useful in the fields of food preservation or safety, health care, and pharmaceutical applications. The inhibition activity of these substances has been reported to be straindependent.

Poltavska and Kovalenko (2012) reported that Bifidobacterium sp. 278 and B. bifidum 174 strains produced bacteriocins of wide spectrum of activity. Bolognani et al. (1997) reported the great efficiency of $B b$. longum to bind carcinogens that produced by aflatoxigenic fungi. Bifidobacterium sp. Bif. 4 exerted a biostatic effect on the fungal growth due to the accumulation of lactic and other organic acids which lead to lowering the $\mathrm{pH}$ of the medium increasing the titratable acidity in the mixtures. Bifidobacterium longum (Bb-46) is a heterofermentative bacterium which produces acetic acid, ethanol, carbonyl compounds and CO2 (Tamime et al., 1995, Tratnik, 1998).

3.5. Determination of antifungal metabolites produced by the lactic acid bacterial (LAB) strains

3.5.1. Analysis of the organic acids by the High Performance Liquid Chromatography (HPLC)

The types and contents of organic acids in the supernatant of the twelve lactic acid bacteria were evaluated by reverse-phase High Performance Liquid Chromatography (HPLC).

The results revealed that there were ten types of organic acids obtained in the supernatant of the LAB, including oxalic, maleic, acetic, citric, succinic, lactic, formic, propionic, butyric and mallic acids.

From the results in (Table 9), it was observed that the main organic acids produced in the studied strains were lactic and acetic acids. These acids were followed by succinic acid and propionic acids. As the highest organic acids produced by LAB were lactic acid $(2.64 \mathrm{mg} / \mathrm{ml})$ and acetic acid $(1.72 \mathrm{mg} / \mathrm{ml})$ after 48 hours respectively. These acids were followed by propionic acid $(1.04 \mathrm{mg} / \mathrm{ml})$ after 48 hours and citric acid $(0.74 \mathrm{mg} / \mathrm{ml})$.

L. rhamnosus was the highest strain in the production of lactic acid $(2.64 \mathrm{mg} / \mathrm{ml})$ and acetic acid $(1.72 \mathrm{mg} / \mathrm{ml})$ after 48 hours, respectively.

Stiles, (2002) indicated that L. rhamnosus VT1 also inhibited mold growth and it has been reported that lactic and acetic acids are the main organic acids involved in antimicrobial activity of Lactobacillus strains (Corsetti et al., 1998).

Plockova et al. (2001) reported that $L$. rhamnosus inhibits the growth of Aspergillus, Penicillium and Fusarium. Cabo et al. (2002) revealed that the synergistic effect of the acetic acid and the lactic acid produced were likely the main factor responsible for the antifungal properties of the selected bacteria. These results could explain some discrepancies in reports of the antifungal properties of lactic acid bacteria, since the role of acetic acid has not been considered in previous studies. 
Table (9): The main organic acids produced in the supernatants of LAB strains.

\begin{tabular}{|l|c|c|c|c|}
\hline \multirow{2}{*}{\multicolumn{1}{|c|}{ Lactic acid bacterial strains }} & \multicolumn{4}{c|}{ Organic acids (mg/ml) } \\
\cline { 2 - 5 } & Lactic acid & Acetic acid & Propionic acid & Citric acid \\
\hline Lactobacillus acidophilus NRRL-B-4495 & 1.56 & 0.90 & 0.68 & 0.41 \\
\hline Lactobacillus acidophilus ATCC 20552 & 2.00 & 0.80 & 0.50 & 0.49 \\
\hline Lactobacillus acidophilus LA3 & 1.47 & 0.70 & 0.60 & 0.39 \\
\hline Lactobacillus acidophilus & 1.21 & 0.92 & 0.65 & 0.74 \\
\hline Streptococcus thermopiles ATCC-3 & 1.60 & 0.57 & 1.04 & 0.48 \\
\hline Streptococcus thermophiles & 1.90 & 0.78 & 0.56 & 0.60 \\
\hline Lactobacillus plantarum ATCC 14917 & 2.09 & 1.06 & 0.86 & 0.61 \\
\hline Lactobacillus rhamnosus & 2.64 & 1.72 & 0.67 & 0.68 \\
\hline Bifidobacterium lactis(Bb12) & 1.77 & 1.07 & 0.47 & 0.39 \\
\hline Bifidobacterium longum & 1.35 & 0.81 & 0.53 & 0.46 \\
\hline Bifidobacterium bifidium & 1.99 & 0.81 & 0.47 & 0.62 \\
\hline Lactobacillus casei DSM 20011 & 1.87 & 0.92 & 0.48 & 0.51 \\
\hline
\end{tabular}

Additionally, Casal et al. (1996) showed that some acids, like acetic acid, can be transported across the cell membrane by inducible permeases. While inside the cell, the protonated acid dissociates into anions, which accumulate in the cytoplasm and cause acidification of the cytoplasm (Stratford and Eklund 2003), thereby causing loss of viability and cell destruction (Torino et al., 2001 Sathe et al., 2007). This fact would explain the differences in activity observed among the acids and the higher antifungal effect obtained at a $\mathrm{pH}$ beneath their $\mathrm{pKa}$. The pKa value of the most common acids produced by lactic acid bacteria are below 5.0. The pKa of lactic and acetic acids is 3.8 and 4.7, respectively.

Doyle et al. (2002) reported the antifungal activity of acetic acid against Aspergillus, Penicillium and Rhizopus spp. And some strains of Saccharomyces. Lind et al. (2005) studied the effect of the three organic acids such as propionic acid, acetic and lactic acid and reported that propionic acid, followed by acetic and lactic acid are the most potent antifungal acids. Lactic acid has shown antifungal activity against the two fungal isolates each of $A$. luchuensis and A. flavus.

\section{Conclusions}

From the available data on the effect of LAB on mold growth and mycotoxin production, it would appear that LAB strains have the potential as biological control agents in foods to repress aflatoxinogenic mold growth through the production of several antifungal metabolites such as organic acids, bacteriocins, antibiotics and other products like ethanol, hydrogen peroxide, carbon dioxide, diacetyl, acetaldehyde etc. As it could be used as a natural, safe, effective, food-grade biocontrol agent and food industries for management of problems caused by aflatoxin-producing Aspergilli.

\section{REFERENCES}

Adebayo C. O. and Aderiye B. I. (2008). Antibacterial activity of bacteriocin from indigenous fermented foods. Int. Res., 4:25-32.

Aunsbjerg S. D, Honoré A. H, Marcussen J., Ebrahimi P., Vogensen F. K., Benfeldt C., Skov T., Knøchel S. (2015) Contribution of volatiles to the antifungal effect of Lactobacillus paracasei in defined medium and yogurt. Int J Food Microbiol. Feb 2;194:46-53.

Batish V.K., Grover S. and La1 R. (1989). Screening lactic starter cultures for antifungal activity. Cultured Dairy Prod. J., 24: 21-25.

Batish V. K., Lal R. and Chander H. (1990a). Effect of nutritional factors on the production of antifungal substance by Lactococcus lactis subsp. lactis biovar diacetylactis. Aust. J. Dairy Technol, 45:74-76.

Batish V. K., Lal R. and Grover S. (1990b). Studies of environmental and nutritional factors on production of antifungal substance by Lactobacillus acidophilus R. Food Microbiol. 7, 199-206.

Bolognani F., Rumney C.J. and Rowland R. (1997). Influence of carcinogen binding by lactic acid producing bacteria on tissue distribution and in vivo mutagenicity of 
dietary carcinogens. Food Chem. Toxicol., 35: 535-545.

Cabo M. L., Braber A. F. and Koenraad P. (2002). Apparent antifungal activity of several lactic acid bacteria against Penicillium discolor is due to acetic acid in the medium. J. Food Protect, 65: 13091316.

Casal M., H. Cardoso, and C. Leao. 1996. Mechanisms regulating the transport of acetic acid in Saccharomyces cerevisiae. Microb, 142:1385-1390.

Coallier-Ascah J. and Idziak E.S. (1985) Interaction between Streptococcus lactis and Aspergillus flavus on production of aflatoxin. Appl. Environm. Microbiology 49: $163-167$.

Çon A.H. and Gökalp H.Y. (2000). Production of bacteriocin-like metabolites by lactic acid cultures isolated from sucuk samples. Meat Sci., 55: 89-96.

Corsetti A., Gobetti M., Rossi J. and Damiani P. (1998). Antimould activity of sourdough lactic acid bacteria: identification of a mixture of organic acids produced by Lactobacillus sanfrancisco CB1. Appl. Microbiol. Biotechnol., 50: 253-256.

Dalié D.K.D., Deschamps A.M. and RichardForget F., (2010). Lactic acid bacteria Potential for control of mould growth and mycotoxins: A review. Food Control 21: 370-380.

Doyle MP, Beuchat L R, Montville T.J. (2002). Food Microbiology: Fundamentals and Frontiers, $2^{\text {nd }}$ ed.ASM Press, Washington, D. C., pp. 768 .

Domsch K.H., Gams W., Anderson T.H. (1980). Compendium of soil fungi. London, England: Academic Press., 865 p.

El-Gendy S. M. and Marth E. H. (1981). Growth and aflatoxin production by Aspergillus parasticus in the presence of Lactobacillus casei. J. Food Protect, 44: 211-212

El-Nezami H. and Ahokas J. (1998). Lactic acid bacteria: an approach for detoxification of aflatoxins. In Lactic Acid Bacteria Microbiology and Functional Aspects, $2^{\text {nd }}$ ed. Salminen, S. and von Wright, A. ed. pp. 359-367. Marcel Dekker, New York:,USA.

El-Nezami H., Kankaanpa“a” P., Salminen S. and Ahokas J. (1998a). Physicochemical alterations enhance the ability of dairy strains of lactic acid bacteria to remove aflatoxin from contaminated media. J. Food Protect., 61: 466-468.

El-Nezami H., Kankanpa“a” P., Salminen S. and Ahokas J. (1998b) Ability of dairy strains of lactic acid bacteria to bind a common food carcinogen, aflatoxin B1. Food and Chem. Toxicol. 36:321-326.

El-Shafei K., Hegazy E. M. and Sadek Z. I. (2010): Ability of immobilized starter cell and metabolites to suppress the growth rate and aflatoxin production by Aspergillus flavus in butter. J. Amer. Sci., 6 (7): 131-138.

Ghonaimy A. G., Abo-Ela M. F. and Yonis A. A. M. (2007). Inhibition of Aspergillus flavus and A. parasiticus fungal growth and its aflatoxins (B1, B2, G1 and G2) production by Lactobacillus acidophilus. (In press.)

Gobetti M. and Corsetti A. (1997). Lactobacillus sanfrancisco, a key sourdough lactic acid bacterium: a review. Food Microbiol, 14: 175-187.

Gourama H. and Bullerman L. B. (1995). Inhibition of growth and aflatoxin production of Aspergillus flavus by Lactobacillus species. J. Food Protect. 58: 1249-1256.

Gourama H. and Bullerman L. B. (1997) Antiaflatoxigenic activity of Lactobacillus casei pseudoplantarum. Intel. J. Food Microbiol., 34: 131-143

Gourama H. (1997). Inhibition of growth and mycotoxin production of Penicillium by lactobacillus species. Lebensm.-Wiss. Technol. 30: 279-1280.

Hanlin RT. (1990). Illustrated genera of ascomycetes. St. Paul, Minnesota: The Ameri. Phytophatol. Soc. P.263

Haskard C.A., El-Nezami H.S., Kankaanpa"a" P., Salminen S. and Ahokas J. (2001). Surface binding of aflatoxin B1 by lactic acid bacteria. Appl. Environm. Microbiol., 67:3086-3091.

Hermandez M.A, Garcia H.S and Steele J.L (2009). Screening of Lactobacillus casei strains for their ability to bind aflatoxin B1. Food and Chem. Toxicol. 47: 10641068.

Hwang K.-C., Lee W., Kim G.-Y., Lee S.-K., Lee J. and Jun W. (2005). The binding of aflatoxin B1 modulates the adhesion properties of Lactobacillus casei KCTC 3260 to a HT29 colon cancer cell line. Food Sci. Biotechnol., 14: 866-870. 
Irineo Torres (2011). Aflatoxins - Detection, Measurement and Control. ISBN 978953-307-711-6.

Kiffer E., Morelet M. (1997). Les deutéromycètes. Classification et clés d'identification gènérique. Paris, France: INRA Editions. 306 p.

Laitila A., Alakomi H.L., Raaska L., MatillaSandholm T. and Haikara A. (2002). Antifungal activities of two Lactobacillus plantarum strains against Fusarium molds in vitro and in malting of barley. J. Appl. Microbiol. 93, 566-576.

Lavermicocca P., Valerio F., Evidente A., Lazzaroni S., Corsetti A. and, Gobetti M. (2000). Purification and characterization of novel antifungal compounds from the sourdough Lactobacillus plantarum strain 21B. Appl. Environ. Microbiol., 66: 4084-4090.

Lavermicocca P., Valerio F. and Visconti A. (2003). Antifungal activity of phenyllactic acid against molds isolated from bakery products. Appl. Environ. Microbiol., 69: 634-640.

Lee Y.K., El-Nezami H., Haskard C.A., Gratz S., Puong K.Y., Salminen S. and Mykkanen, H. (2003). Kinetics of adsorption and desorption of aflatoxin B1 by viable and nonviable bacteria. J. Food Protect., 66: 426-430

Lind H., Jonsson H. and Schnürer J. (2005). Antifungal effect of dairy propionibacteria -contribution of organic acids. Int, J. Food Microbiol., 98: 157-165.

Luchese R.H., Martins J.F. and Harrigan W.F. (1992). Aflatoxin production in a meat mix model system in the presence of Pediococcus and Lactobacillus. J. Food Protect. 55: 583-587.

Magnusson J. and Schnu"rer J. (2001). Lactobacillus coryniformis subsp. coryniformis strain $\mathrm{Si} 3$ produces a broadspectrum proteinaceous antifungal compound. Appl. Environ. Microbiol., 67: $1-5$.

Mitscher L. A., Leu R., Bathala M. S., Wu W. and Beal J.L. ( 1972). Antimicrobial agents from higher plants. Introduction, rational, and methodology. Lloydia, 35: 157-166.

Motawee M. M. and Abd El-Ghany M. A. (2011). Effect of some lactic acid bacteria strains on aflatoxins reduction in some dairy foods. The $6^{\text {th }}$ Arab and $3^{\text {rd }}$
International Annual Scientific Conference on: Development of Higher Specific Education Programs in Egypt and the Arab World in the Light of Knowledge Era Requirements. Mansoura University, Egypt. 13(4): 2111-2124.

Niku-Paavola M.L., Laitila A., MatillaSandholm T. and Haikara A. (1999). New types of antimicrobial compounds produced by Lactobacillus plantarum. J. Appl. Microbiol., 86: 29-35.

Ogunbanwo S.T. (2005). Functional properties of lactic acid bacteria isolated from ogi and fufu, two Nigerian fermented foods. Adv. Food Sci., 27: $14-20$.

Okkers D.J., Dicks L.M.T., Silvester M., Joubert J.J. and Odendaal H.J. (1999). Characterization of pentocin TV35b, a bacteriocin-like peptide isolated from Lactobacillus pentosus with a fungistatic effect on Candida albicans. J. Appl. Microbiol., 87: 726-734.

Onilude A. A.; Fagade O. E.; Bello M. M. and Fadahunsi I. F. (2005). Inhibition of aflatoxin producing aspergilli by lactic acid bacteria isolates from indigenously fermented cereal gruels. Afr. J. Biotech., 4 (12): 1404-1408.

Oranusi S. , Braide W., Oguoma O. I. (2013). Antifungal properties of lactic acid bacteria (LAB) isolated from Ricinus communis, Pentaclethra macrophylla and Yoghurts. 002. Glo. Adv. Res. J. Food. Sci. Technol. , 2(1) :1-6.

Parish M. E. and Davidson P. M. (1993). Methods for evaluation. In: Antimicrobials in Foods, 2nd edition. eds. Davidson, P.M. and Branen, A.L. pp. 597615. Marcel Dekker Inc., New York, USA.

Pitt J.J. and Hocking, A.D. (2009). Spoilage of stored, processed and preserved foods. Fungi and food spoilage $3^{\text {rd }}$ ed. Springer, NewYork: 2009. pp. 401-421.

Plockova' M., Chumchalova' J. and Tomanova' J. (1997a). Antifungal activity of Lactobacillus acodophilus CH5 metabolites. Food Sci., 15: 39-48.

Plockova' M., Tomanova' J. and Chumchalova' J. (1997b). Inhibition of mould growth and spore production by Lactobacillus acidophilus CH5 metabolites. Bull. Food Res., 36: 237-247.

Plockova M., Stilesm J., Chumchalova J., Halfarova R. (2001) Control of mould 
growth by Lactobacillus rhamnosus VT1 and Lactobacillus reuteri CCM 3625 on milk agar plates. Czech J Food Sci., 19: 46-50.

Poltavska O.A., Kovalenko N.K. (2012). Antimicrobial activity of bifidobacterial bacteriocin-like substances. Mikrobiol., Z. , 74:(5):32-42.

Roy U., Batish V.K., Grover S. and Neelakantan S. (1996). Production of antifungal substance by Lactococcus lactis subsp. lactis CHD-28.3. Int. J. Food Microbiol., 32: 27-34.

Roy U., Grover S., Neelakantan S. and Batish V.K. (2001). Mode of inhibition of Aspergillus flavus IARI antifungal substance produced by Lactococcus lactis subsp. Lactis CHD-28.3. J. Food Sci. Technol., 38: 489-492

Sathe S. J., Nawani N. N., Dhakephalkar P. K. and Kapadnis B. P.(2007). Antifungal lactic acid bacteria with potential to prolong shelf-life of fresh vegetables. J. Appl. Microbiol., 103: 2622-2628.

Schnürer J. and Magnusson J. (2005). Antifungal lactic acid bacteria as biopreservatives. Trends in Food Sci. and Techn., 16: 7078.

Siriporn S., Ladda W. and Aree S. (2003). Antiaflatoxigenic effect of lactic Acid bacteria isolated from some Thai Fermented Foods. Kasetsart J. (Nat. Sci.), 37: $65-71$.

Stratford M. and Eklund T. (2003). Organic acids and esters. p. 48-84. In N.J. Russell, and G.W. Gould (ed.), Food preservatives Kluwer Academic/Plenum Publishers, New York, N.Y

Ström K., Sjörgen J., Broberg A. and Schnürer J. (2002). Lactobacillus plantarum MiLAB 393 produces the antifungal cyclic dipeptides cyclo (L-Phe-L-Pro) and cyclo (L-Phe-trans-4-OH-L-Pro) and 3 phenyllactic acid. Appl. Environ.
Microbiol. , 68: 4322-4327.

Stiles J., Plockova' M., Toth V. and Chumchalova' J. (1999). Inhibition of Fusarium sp. DMF 0101 by Lactobacillus strains grown in MRS and Elliker broth. Adv. Food Sci., 21: 117-121.

Stiles J., Penkar S., Plockova' M., Chumchalova' J. and Bullerman L.B. (2002). Antifungal activity of sodium acetate and Lactobacillus rhamnosus. J. Food Prot., 65: 1188-1191.

Suzuki I., Nomura M. and Morichi T. (1991). Isolation of lactic acid bacteria which suppress mold growth and show antifungal action. Milchwissenschaft, 46: 635-639.

Tamime A.Y., Marshall V.M.E., Robinson R.K. (1995). Microbiological and technological aspects of milks fermented by bifidobacteria. J. Dairy Res., 62: 151-187.

Torino M. I., Taranto M. P., Sesma F. and Font de Valdez G. (2001). Heterofermentative pattern and exopolysaccharide production by Lactobacillus helveticus ATCC 15807 in response to environmental $\mathrm{pH}$. J. Appl. Microbiol., 91: 846-852.

Tratnik Lj. (1998). Fermented milk drinks. In: Milk- technology, biochemistry and microbiology, office. Volaric, V., Croatain Dairy Union, Zegreb, 129 -181.

Vanne L., Kleemol T. and Haikara A. (2000). Microbial assessment and quality evalution of ogi during spoilage. World $\mathbf{J}$. Microbiol. Biotech. , 18: 731-737.

Von Arx J.A. (1981). The genera of fungi sporulating in pure culture. Vaduz, Germany: J. Cramer. 424 p. during spoilage. World J. Microbiol. biotech., 18: 731-737.

Zinedine A., Faid M. and Benlemlih M. (2005). In vitro reduction of aflatoxin $\mathrm{B} 1$ by strains of lactic acid bacteria isolated from Moroccan sourdough bread Int. J. Agr. Biol., 7: 67-70. 


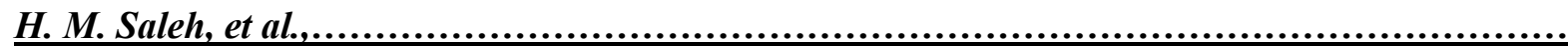

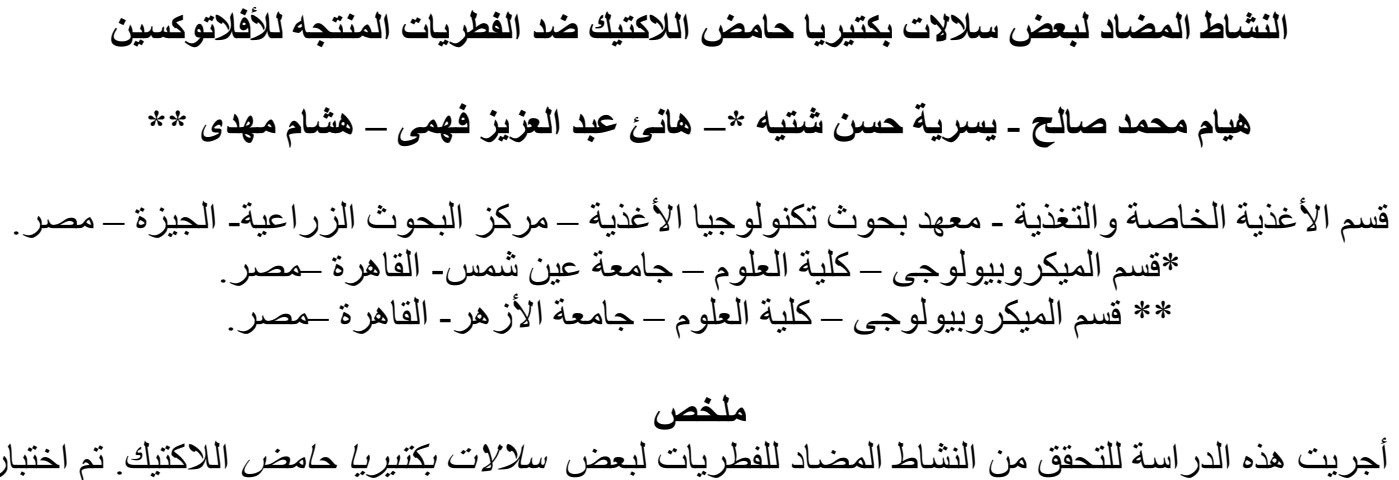

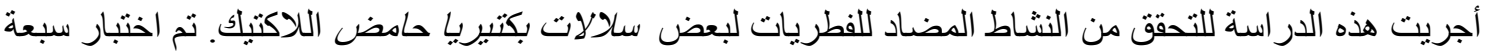

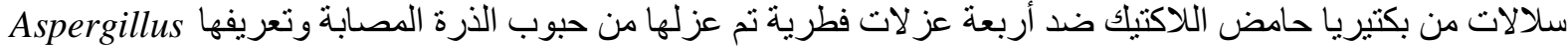
Rhizopus nigricans و Aspergillus niger و Aspergillus parasiticus glavus الكتلة الحيوية للفطريات بمثابة اختبار قبل الفحص. تم الكثف عن العزلات الات الفطرية المنتجة للافلاتوكسين باستخدام طريقة

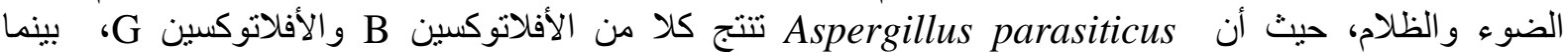
ينتج الأفلاتوكسين Bspergillus flavus

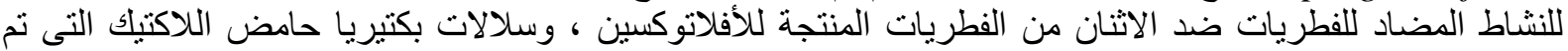
اختبار ها هى (Lactobacillus acidophilus ATCC 20552 و Lactobacillus acidophilus NRRL-B-4495 Lactobacillus plantarum ATCC 14917, Lactobacillus acidophilus LA3, Lactobacillus casei DSM - Bifidobacterium bifidium ، Lactobacillus acidophilus ، Lactobacillus rhamnosus ، 20011 Streptococcus thermophiles g Streptococcus thermophiles‘Bifidobacterium longum ATCC 15708

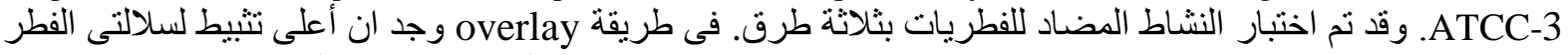


Aspergillus flavus وجد أن أعلى تثبيط لسلالة كان بو اسطة السلالات

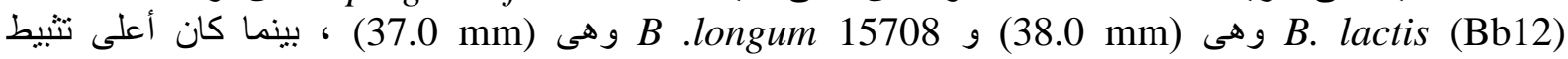

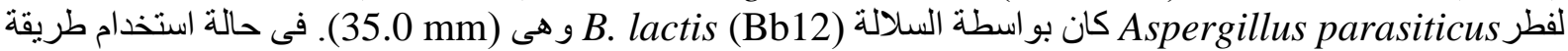



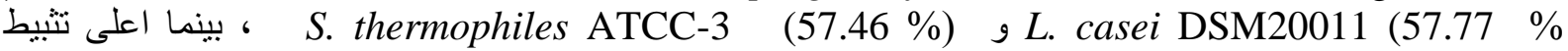

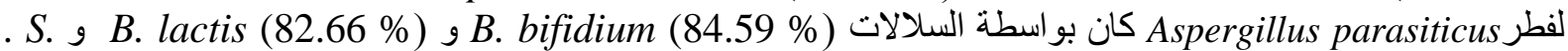
thermophiles ATCC-3 (68.69\%)

قد يكون هذا التثبيط بسبب انتاج المركبات المضادة للفطريات مثل الأحماض العضوية، فوق أكسيد الهيدروجين

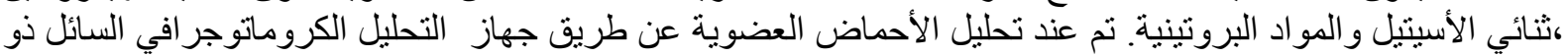

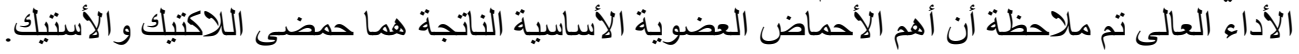

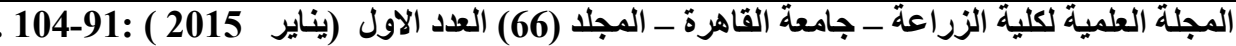

